\title{
FRUIT LAXATIVES AND SEED PASSAGE RATES IN FRUGIVORES: CONSEQUENCES FOR PLANT REPRODUCTIVE SUCCESS ${ }^{1}$
}

\author{
K. Greg Murray, Susan Russell, Christopher M. Picone, ${ }^{2}$ \\ KATHY WINNETT-MURRAY, WENDY SHERWOOD, AND \\ MARK L. KUHLMANN ${ }^{3}$ \\ Department of Biology, Hope College, Holland, Michigan 49423 USA
}

\begin{abstract}
To explore how plants may influence dispersal of their own seeds by manipulating the behavior and physiology of their dispersers, we studied the effect of a soluble chemical (or chemicals) in the fruits of Witheringia solanacea (Solanaceae), a Costa Rican cloud forest shrub, on passage of its seeds through the guts of one of its major dispersers, the Black-faced Solitaire, Myadestes melanops (Muscicapidae: Turdinae). Using artificial fruits containing natural seeds, we found that the presence of a crude pulp extract reduced the median seed retention time by nearly $50 \%$. Estimation of seed dispersal distance as a function of retention time suggested that more rapid seed passage results in shorter average dispersal distances, especially for seeds retained $<20 \mathrm{~min}$. At the same time, germination trials revealed that seeds voided rapidly were far more likely to germinate than those remaining longer in Myadestes guts. We propose that "laxative" chemical(s) in Witheringia fruits balance these positive and negative consequences of ingestion by Myadestes.
\end{abstract}

Key words: Costa Rica; frugivory; "laxative" chemicals; Myadestes melanops; seed dispersal; seed germination; Witheringia solanacea.

\section{INTRODUCTION}

Ever since McKey's (1975) influential paper on plantfrugivore coevolution, a recurrent theme in the study of seed dispersal mutualisms has concerned the degree to which plants can influence disperser behavior in order to maximize their own reproductive success. Most studies have concentrated on plant characteristics that serve to increase the likelihood of frugivore visitation or the rate at which they remove fruits (e.g., Howe and Estabrook 1977, Thompson and Willson 1979, Howe and Vande Kerckhove 1980, Stiles 1980, Herrera 1981, Sorensen 1981, 1983, 1984, Levey et al. 1984, Johnson et al. 1985, Murray 1987, Skeate 1987, Murray et al. 1993). Plant characteristics that influence reproductive success by manipulating disperser physiology have received much less attention. In many bird species large seeds are voided by regurgitation while smaller ones are defecated (Sorensen 1984, Johnson et al. 1985, Levey 1986,1987 , Murray et al. 1993). As a result, small seeds are retained longer in the gut and might travel farther from the parent plant, even though longer retention might reduce seed viability. A recent study by Levey and Grajal (1991) demonstrated the negative relationship between seed size and retention time in

\footnotetext{
' Manuscript received 1 February 1993; revised and accepted 31 August 1993; final version received 27 September 1993.

2 Present address: Department of Biology, University of Michigan, Ann Arbor, Michigan 48109-1048 USA.

${ }^{3}$ Present address: Department of Biological Sciences, Florida State University, Tallahassee, Florida 32306 USA.
}

Cedar Waxwings, even among seeds that are invariably defecated.

We report here the results of experiments that demonstrate the influence of a soluble fruit chemical (or chemicals) on seed passage rates of a Costa Rican cloud forest plant. We show that the "laxative" chemical(s), which reduce(s) seed retention times and thus lead(s) to more restricted seed shadows, may actually increase plant fitness by reducing mortality of seeds retained in the gut for long periods of time.

\section{Study Site AND Methods}

Data were collected from 12 June to 12 August 1990 and 11 June to 26 July 1991 in the Monteverde Cloud Forest Reserve, Provincia de Puntarenas, Costa Rica $\left(10^{\circ} 18^{\prime} \mathrm{N}, 84^{\circ} 48^{\prime} \mathrm{W}\right)$. Most of the reserve, which straddles the continental divide and includes some 10000 ha, consists of pristine Lower Montane Rain Forest (LMRF; Holdridge life zone classification system, Holdridge 1967) and Lower Montane Wet Forest (LMWF). Fruits and birds used in experiments reported here were collected in the transition zone between LMRF and LMWF, at $\approx 1450-1550 \mathrm{~m}$. Thorough descriptions of the geography, climate, and forest types of the reserve are provided by Lawton and Dryer (1980).

The plant species used in this study, Witheringia solanacea (Solanaceae), is a common pioneer (i.e., gap dependent) shrub in forests from sea level to $2000 \mathrm{~m}$ (Standley 1937), and ranges from Mexico to Brazil (D'Arcy 1973). Previous studies at Monteverde by one of us (K. G. Murray) showed that the major disperser 


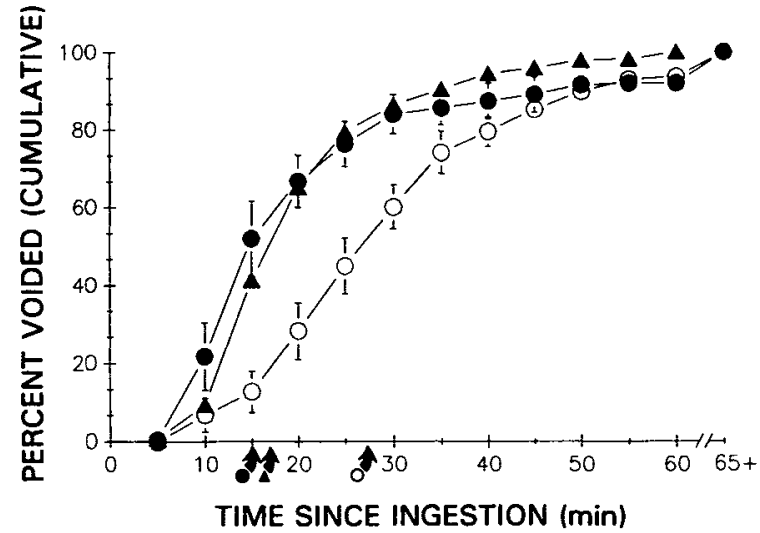

Fig. 1. Cumulative passage time distributions for Witheringia solanacea seeds in three fruit types: natural fruits $(\boldsymbol{\Delta})$, artificial fruits with pulp extract (O), and artificial fruits without extract $(O)$. Error bars indicate \pm 1 SE. Arrows below the $x$ axis represent median retention times. Total numbers of seeds were 1366,232 , and 336 for natural fruits, artificial fruits with pulp extract, and artificial fruits without extract, respectively. Data on natural fruits are from Murray (1988) and lack error bars because data were collected differently in that study.

of $W$. solanacea at Monteverde is the Black-faced Solitaire, Myadestes melanops (Muscicapidae: Turdinae); of all $W$. solanacea seeds recovered from frugivore feces in an intensive 2-yr study, nearly all came from M. melanops (Murray 1988).

Captive $M$. melanops were maintained in separate $0.5 \times 0.5 \times 0.5 \mathrm{~m}$ cages during and between experiments, and were provided with food and water ad libitum at all times. Maintenance food consisted of natural fruits commonly eaten by $M$. melanops (primarily Conostegia bernouliana and Gonzalagunia rosea) and an "artificial" maintenance diet similar to that described by Denslow et al. (1987). All birds ate the diet readily and maintained approximately constant mass for the captive period. Most birds were held for 3-5 d, and all were released unharmed.

Seed passage rates. - Seed passage rates were determined as described by Murray (1988). After removing maintenance food from the cage, we presented each bird with 10 experimental fruits, either on a wire "infructescence" or in a petri dish attached to the perch. Five minutes after the first fruit was consumed, all remaining fruits were removed, and the maintenance food was replaced in the dish. The midpoint of the 5 -min consumption interval was then considered as the time of ingestion for all experimental fruits. At 5 -min intervals thereafter a single sheet of newspaper was removed from the cage floor, and all defecated seeds were recovered and counted.

Chemical control of seed passage rate.-To determine whether fruit chemicals affect seed passage rates, we constructed artificial "fruits" from a solution of 2.0 $\mathrm{g}$ agar, $7.5 \mathrm{~g}$ glucose, $7.5 \mathrm{~g}$ fructose, $100 \mathrm{~mL}$ boiling water, and 45 drops of red food coloring. The hot mix- ture was injected into a spherical mold $(7.75 \mathrm{~mm}$ diameter) containing 10 Witheringia solanacea seeds. Half of the artificial fruits so produced were soaked in a small amount of crude extract from $W$. solanacea fruits (prepared by simply crushing natural fruits and discarding the seeds, pulp, and fruit skins) overnight before retention time experiments. Thus we obtained two types of artificial fruit identical in all respects save one: the presence/absence of soluble chemicals from $W$. solanacea pulp. With each of six M. melanops, we performed two trials with each fruit type.

Germination success and rate vs. passage rate. -To determine how the length of gut treatment affects germination success (defined as the proportion of seeds germinating), we conducted retention time experiments similar to those described above with natural fruits in five $M$. melanops. Seeds emerging in each 5-min interval were then planted in shallow trays of soil in a large clearing. Germination success of control seeds $(20-40$ seeds carefully removed by hand from fruits of each of the 14 plants used as fruit/seed sources above) was measured in the same way. To prevent additional seed input and disturbance by direct rainfall, trays were protected by a plastic canopy. Seeds were checked approximately every other day and watered when necessary for at least $60 \mathrm{~d}$ after planting. We scored seeds as germinated when the root had penetrated the soil and the cotyledons had fully emerged from the seed coat. Although this is more properly called "establishment" than germination, we use the latter term throughout this paper.

\section{RESULtS}

\section{Seed passage rates}

Birds consumed 1-8 (median 2.8; $n=48$ ) fruits during the 5-min ingestion period, invariably swallowing them whole. In all cases, the first seeds emerged within $10 \mathrm{~min}$ of ingestion, and $\approx 90 \%$ had emerged by 45 $\mathrm{min}$. The resulting retention time distributions (Fig. 1) show that seed passage rates from artificial fruits with pulp extract were very similar to those from natural fruits. In contrast, seeds from artificial fruits without pulp extract were passed significantly more slowly (median passage time $\approx 27 \mathrm{~min}$ ) than those with extract $(\approx 15 \mathrm{~min}$ ) (Kolmogorov-Smirnov $D=0.2429, P<$ .001 ). The presence of some (as yet undetermined) soluble chemical(s) in $W$. solanacea apparently increases seed passage rates in $M$. melanops, perhaps by increasing gut motility.

To verify that the difference in seed passage rate between artificial fruits with and without pulp extract was consistent among individual birds, we compared mean seed retention times between treatments with a two-way ANOVA. Data used in the analysis were the two median retention time determinations per bird per treatment. The effect of the extract was highly significant (Table 1, effect TREATMENT), and although 
TABLE 1. Results of two-way ANOVA on mean retention times of Witheringia solanacea seeds from agar fruits with and without pulp extract. Since TREATMENT is a fixed effect, its Ms is tested over the interaction (BIRD $\times$ TREATMENT) MS rather than over the ERROR MS (See Sokal and Rohlf 1981: 339-340).

\begin{tabular}{lccccc}
\hline \multicolumn{1}{c}{ Source } & ss & df & MS & $F$ & $P$ \\
\hline TREATMENT & 467.65 & 1 & 467.65 & 15.80 & $<.02$ \\
BIRD & 613.09 & 5 & 122.617 & 3.80 & $<.05$ \\
BIRD $\times$ TREATMENT & 147.95 & 5 & 29.59 & 0.92 & $>.5$ \\
Error & 387.17 & 12 & 32.27 & $\cdots$ & $\cdots$ \\
Total & 1615.86 & 23 & $\cdots$ & $\cdots$ & $\cdots$ \\
\hline
\end{tabular}

some individuals passed seeds more rapidly than others overall (effect BIRD), the extract produced similar effects in all individuals (no significant BIRD $x$ TREATMENT interaction).

Consequences of seed passage rate for germination success and dispersal distance

Germination success of $W$. solanacea seeds was strongly affected by gut passage. On the one hand, proportional germination was higher among seeds passed through Black-faced Solitaire guts $(62.8 \%$; all retention times combined) than among those removed from fruits by hand $\left(51.7 \% ; \chi^{2}=12.8, P<.001\right)$. On the other hand, among gut-treated seeds germination success decreased monotonically with increased time spent in the gut (Fig. 2), even though all seeds, regardless of retention time, appeared intact. Thus, short periods of treatment in Black-faced Solitaire guts are advantageous, but this advantage diminishes rapidly with longer retention times. This effect was similar, but not identical, among birds: regression lines fit separately for each of the five birds were parallel, but had different $y$ intercepts (Table 2).

To determine the relationship between retention time and seed dispersal distance, we used a method devised by Murray (1988:297-298) that combines retention time distributions like those in Fig. 1 with data on bird movement patterns. Here, we estimated the median dispersal distance for seeds retained for $5,10,15, \ldots$, $60 \mathrm{~min}$, using $96.2 \mathrm{~h}$ of movement data obtained previously for four $M$. melanops individuals (Murray 1988). Fig. 3 shows that predicted median dispersal distance increases dramatically with increasing retention time up to $\approx 30 \mathrm{~min}$, but only slightly thereafter. The asymptotic increase results from the fact that Blackfaced Solitaires restrict their foraging to reasonably welldefined home ranges.

\section{DisCUSSION}

\section{Effects of gut treatment on germination success}

Numerous studies document enhanced germination success of seeds that pass through the guts of birds (e.g., Noble 1975, Temple 1977, Noble and Whalley 1978, Glyphis et al. 1981, Holthuijzen and Sharik 1985, Barnea et al. 1990, 1991, Izhaki and Safriel 1990) as well as mammals (e.g., Lamprey et al. 1974, Applegate et al. 1979, Lieberman et al. 1979, Fleming and Heithaus 1981, Estrada and Coates-Estrada 1986, Utzurrum and Heideman 1991) compared with those removed from fruits by hand. Such enhancement is far from universal however; many of the studies cited above, as well as others (e.g., Howe and Vande Kerckhove 1981, Lieberman and Lieberman 1986), failed to show any positive effects of gut treatment in some of the fruit-frugivore pairs tested.

Results of the present study suggest that simple comparisons of germination success in seeds ingested by frugivores with those not ingested obscure an important aspect of the plant-frugivore interaction. Although germination success of seeds passed rapidly through Myadestes guts was higher than that of those removed from fruits by hand, viability of those retained longer decreased markedly with increasing passage time (Fig.

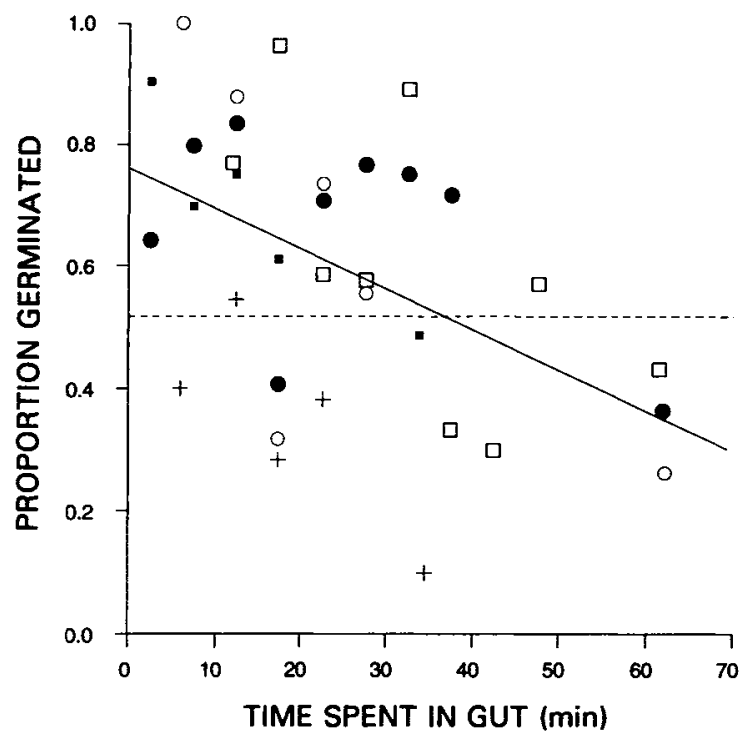

FIG. 2. Germination success of $W$. solanacea seeds vs. retention time in five Myadestes melanops guts. Each point represents the proportion of seeds (retained by one individual for a particular time) that eventually germinated. $\square$ represents bird $1, \square$ bird 2,0 bird 3 , $\bigcirc$ bird 4 , and + bird 5 . Total number of seeds processed was 1355 and ranged from 149 to 508 per bird. The regression equation for all birds combined is $y=0.007 x+0.76 . F$ and $P$ values are 10.1 with $\mathrm{df}=1$, 32 and $P<.005$, respectively. The dashed horizontal line represents germination success of seeds removed from fruits by hand, hence not treated in Black-faced Solitaire guts. 
TABLE 2. Two ANCOVA tests for the effects of treatment in different birds' guts on germination success (data in Fig. 2). (A) Test for homogeneity of slopes (Sokal and Rohlf 1981) among the regressions fitted separately for each of five birds. (B) Test for equivalence of $y$ intercepts among individual regressions. Germination success was arcsine transformed for all analyses.

\begin{tabular}{|c|c|c|c|c|c|}
\hline Source & sS & df & MS & $F$ & $P$ \\
\hline $\begin{array}{l}\text { A) AMONG REGRESSIONS } \\
\text { Error }\end{array}$ & $\begin{array}{r}428.20 \\
3212.70\end{array}$ & $\begin{array}{r}4 \\
24\end{array}$ & $\begin{array}{l}107.05 \\
133.86\end{array}$ & $\begin{array}{c}0.80 \\
\cdots\end{array}$ & $\begin{array}{l}>.5 \\
\cdots\end{array}$ \\
\hline $\begin{array}{l}\text { B) AMONG INTERCEPTS } \\
\text { Error }\end{array}$ & $\begin{array}{l}2307.08 \\
3640.90\end{array}$ & $\begin{array}{r}4 \\
28\end{array}$ & $\begin{array}{l}576.77 \\
130.03\end{array}$ & $\begin{array}{c}4.44 \\
\cdots\end{array}$ & $\begin{array}{c}<.007 \\
\ldots\end{array}$ \\
\hline
\end{tabular}

2). Both effects may result from chemical and/or mechanical abrasion of the seed coat in the gut (cf. Barnea et al. 1990). Mild abrasion may facilitate water imbibition or perception of germination cues (probably light, cf. Vazquez-Yanes 1977, 1980, Vazques-Yanes and Smith 1982, Vazquez-Yanes and Orozco-Segovia 1984). As retention time increases, however, abrasion may be sufficient to damage seeds, perhaps by causing premature germination. All else being equal, we might expect selection for fruit characteristics that result in more rapid seed passage.

\section{Effects of gut treatment on dispersal distance}

Despite the advantage of rapid seed passage acting through seed viability, rapid passage also appears to have negative consequences for plant reproductive success. Seeds voided quickly are deposited nearer the parent plant (Fig. 3), and such reduced dispersal distance is likely to lower reproductive success in at least three ways. First, seeds deposited near their source may suffer from direct competition with the parent plant. Second, since the density of dispersed seeds is a function of dispersal distance, and since many seed and seedling predators forage in a density-dependent manner, seeds voided near the parent may suffer increased predation risk (Howe and Primack 1975, Janzen et al. 1976, Platt 1976, Salmonson 1978, Clark and Clark 1981, Augspurger 1983a, $b, 1984 a, b$, Howe et al. 1985). Third, for pioneer species like $W$. solanacea, repro-

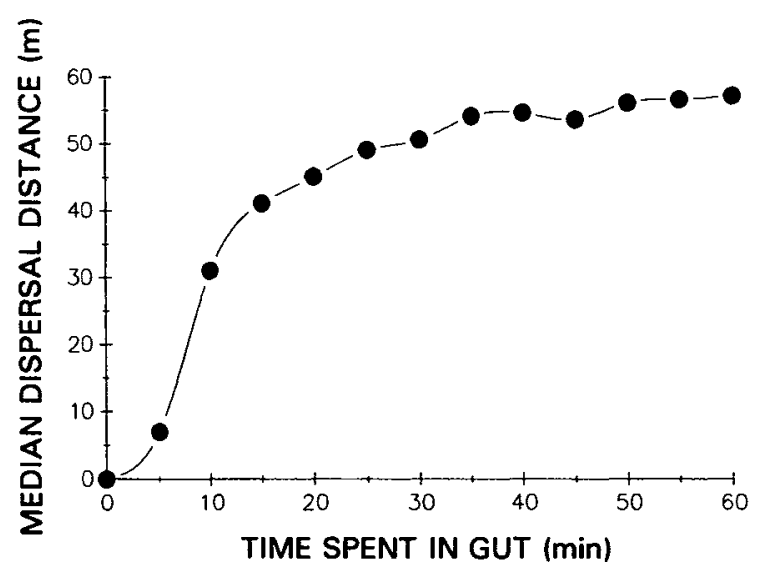

Fig. 3. Median seed dispersal distance as a function of time spent in Myadestes melanops guts. ductive success depends strongly on dispersal distance, since seeds deposited nearer their parents are less likely to encounter recently opened gaps (Murray 1988). Especially in pioneers then, we might expect selection to favor not faster, but slower seed passage. Despite the advantages of greater dispersal distance, however, very long seed retention times are unlikely to result in everincreasing dispersal distances. As Fig. 3 shows, median dispersal distance increases little for seeds retained longer than $30 \mathrm{~min}$, because Black-faced Solitaires forage on well-defined home ranges.

\section{Effects of fruit "laxatives"}

To our knowledge, this is the first study to demonstrate the existence of a soluble fruit chemical (or chemicals) that mediates seed passage rate: seeds from artificial fruits that also included a crude extract from $W$. solanacea pulp were voided much more rapidly than seeds from fruits without the extract (Fig. 1). The implication of a laxative chemical is strengthened by the fact that the retention curve for artificial fruits treated with pulp extract is almost indistinguishable from that for natural fruits.

It is tempting to propose that fruit chemicals that increase seed passage rates have evolved in response to conflicting selection pressures imposed by the seed viability vs. dispersal distance trade-off suggested above. However, since we lack detailed knowledge of the precise nature of the trade-offs between fitness components associated with germination success and dispersal distance, such an adaptive explanation for the existence of a laxative chemical must remain speculative.

Laxative chemicals may have other effects as well. If fruit laxatives increase the frequency of defecation, for example, seeds from a given fruit might be deposited in a greater number of fecal clumps (cf. Putz 1993). Presumably, both predation and competition would be reduced for seeds in smaller clumps. Although we did not collect data on seed number per individual defecation in this study, our results suggest that the laxative in Witheringia pulp may actually decrease the number of sites at which seeds from a given fruit are deposited: the variance in percentage of seeds emerging in each 5 -min time interval was actually higher for seeds from fruits with pulp extract (86.9) than for those from fruits without it (32.7). At least in Witheringia then, laxative 
chemicals are more likely to decrease, rather than increase, reproductive success via effects on seed clump size.

Laxative chemicals might indirectly affect fruit preferences as well. Recent studies with artificial fruits show that rapid seed passage makes possible higher fruit consumption rates in Cedar Waxwings (Bombycilla cedrorum; Levey and Grajal 1991) and American Robins (Turdus migratorius; Murray et al. 1993) and that many birds form strong preferences for fruits whose seeds are passed most rapidly. Working with natural fruits, Sorensen (1984) also found that feeding preferences of European Blackbirds (Turdus merula) were correlated with seed passage rates. Presumably, the effects of a laxative chemical would even extend to other fruits present in the gut at the same time. Birds might thus derive benefits from fruits like $W$. solanacea that are entirely unrelated to the nutrient content of the fruits themselves. By consuming small numbers of $W$. solanacea fruits, birds may be able to increase the rate at which they can consume and process all fruits. On the other hand, more rapid passage of gut contents may be at the expense of complete extraction of nutrients from the fruit pulp. Indeed, frugivores in general are notorious for intrinsically rapid processing rates, and Karasov and Levey (1990) explain these as a strategy to increase the net rate of energy gain from nutrientpoor foods by process-limited animals. Future work with $W$. solanacea and other species should focus on identifying the chemicals responsible for rapid seed passage as well as exploring their consequences for feeding efficiency in birds on mixed-fruit diets.

\section{Consequences of intraspecific variation in gut treatment effects}

Individual Myadestes used in this study varied significantly in both seed passage rates (Table 1) and treatment effects on seed viability (Fig. 2, Table 2). Such variation has important general implications for studies of plant-frugivore interactions. Obviously, if we hope to detect and interpret differences in the fitness consequences to plants of ingestion by different species of dispersers, we must first understand the extent and nature of variation in treatment effects within species. Some studies have based comparisons of treatment effects on fewer than four individuals of some bird species (e.g., Levey 1986, Murray 1988, Izhaki and Safriel 1990). Izhaki and Safriel (1990), for example, suggest that the differential effects of ingestion by different bird species on germination rate serve to spread the risk associated with synchronous germination. If significant variation exists within bird species, however, we might overestimate the fitness advantages of a broad disperser coterie relative to those of a single disperser species. Future studies should include adequate replication in order to accurately represent the variation within disperser species as well as allow meaningful comparisons among different ones.

\section{ACKNOWLEDGMENTS}

Personnel of the Tropical Science Center (especially W. Aspinall, G. Bello, and J. Tosi) kindly facilitated our use of the Monteverde Cloud Forest Reserve. D. Levey and C. Martinez del Rio provided invaluable criticism of an earlier version of the manuscript, and R. Boyce, B. Keas, S. Kulp, T. Long, E. Lundquist, and R. Ostertag assisted with field work. The authors were supported by NSF grants BSR-9006734 and BSR-9146650 and an American Philosophical Society grantin-aid to K. G. Murray and NSF REU grants (BBS-8712566, BBS-8804082, DIR-9000984, and BBS-9100398) to Hope College.

\section{Literature Cited}

Applegate, R. D., L. L. Rogers, D. A. Castell, and J. M. Novak. 1979. Germination of cow parsnip from grizzly bear feces. Journal of Mammalogy 60:655.

Augspurger, C. K. 1983a. Offspring recruitment around tropical trees: changes in cohort distance with time. Oikos 40:189-196.

- $1983 b$. Seed dispersal by the tropical tree, Platypodium elegans, and escape of its seedlings from fungal pathogens. Journal of Ecology 71:759-771.

- 1984a. Pathogen mortality of tropical tree seedlings: experimental studies of the effects of dispersal distance, seedling density, and light conditions. Oecologia 61:211217.

- 1984b. Seedling survival of tropical tree species: interactions of dispersal distance, light-gaps, and pathogens. Ecology 65:1705-1712.

Barnea, A., Y. Yom-Tov, and J. Friedman. 1990. Differential germination of two closely related species of Solanum in response to bird ingestion. Oikos 57:222-228.

Barnea, A., Y. Yom-Tov, and J. Friedman. 1991. Does ingestion by birds affect seed germination? Functional Ecology 5:394-402.

Clark, D. A., and D. B. Clark. 1981. Effects of seed dispersal by animals on the regeneration of Bursera graveolens (Burseraceae) on Santa Fe Island, Galapagos. Oecologia 49:7375.

D'Arcy, W. G. 1973. Solanaceae. In R. E. Woodson, Jr. and R. W. Schery, editors. Flora of Panama. Annals of the Missouri Botanical Garden 60:573-780.

Denslow, J. S., D. J. Levey, T. C. Moermond, and B. C. Wentworth. 1987. A synthetic diet for fruit-eating birds. Wilson Bulletin 99:131-134.

Estrada, A., and R. Coates-Estrada. 1986. Frugivory by howling monkeys (Alouatta palliata) at Los Tuxtlas, Mexico: dispersal and fate of seeds. Pages 93-104 in A. Estrada and T. H. Fleming, editors. Frugivores and seed dispersal. W. Junk, Dordrecht, The Netherlands.

Fleming, T. H., and E. R. Heithaus. 1981. Frugivorous bats, seed shadows, and the structure of tropical forests. Biotropica 13 (supplement):45-53.

Glyphis, J. P., S. J. Milton, and W. R. Siegfried. 1981. Dispersal of Acacia cyclops by birds. Oecologia 48:138-141.

Herrera, C. M. 1981. Fruit variation and competition for dispersers in natural populations of Smilax aspera. Oikos 36:51-58.

Holdridge, L. 1967. Life zone ecology. Tropical Science Center, San Jose, Costa Rica.

Holthuijzen, A. M. A., and T. L. Sharik. 1985. The avian seed dispersal system of eastern red cedar (Juniperus virginiana). Canadian Journal of Botany 63:1508-1515.

Howe, H. F., and G. F. Estabrook. 1977. On intraspecific competition for avian dispersers in tropical trees. American Naturalist 111:817-832.

Howe, H. F., and R. B. Primack. 1975. Differential seed dispersal by birds of the tree Casearia nitida (Flacourtiaceae). Biotropica 7:278-283. 
Howe, H. F., E. W. Schupp, and L. C. Westley, 1985. Early consequences of seed dispersal for a neotropical tree (Virola surinamensis). Ecology 66:781-791.

Howe, H. F., and G. A. Vande Kerckhove. 1980. Nutmeg dispersal by tropical birds. Science 210:925-927.

Howe, H. F., and G. A. Vande Kerckhove. 1981. Removal of wild nutmeg (Virola surinamensis) crops by birds. Ecology 62:1093-1106.

Izhaki, I., and U. N. Safriel. 1990. The effect of some mediterranean scrubland frugivores upon germination patterns. Journal of Ecology 78:56-65.

Janzen, D. H., G. A. Miller, J. Hackforth-Jones, C. M. Pond, D. Hooper, and D. P. Janos. 1976. Two Costa Rican bat generated seed shadows of Andira inermis (Leguminosae). Ecology 56:1068-1075.

Johnson, R. A., M. F. Willson, J. N. Thompson, and R. I. Bertin. 1985. Nutritional values of wild fruits and consumption by migrant frugivorous birds. Ecology 66:819827.

Karasov, W. H., and D. J. Levey. 1990. Digestive system trade-offs and adaptations of frugivorous passerine birds. Physiological Zoology 63:1248-1270.

Krebs, C. J. 1989. Ecological methodology. Harper \& Row, New York, New York, USA.

Lamprey, H. F., G. Halevy, and S. Makacha. 1974. Interactions between Acacia, bruchid seed beetles and large herbivores. East African Wildlife Journal 12:81-85.

Lawton, R., and V. Dryer. 1980. The vegetation of the Monteverde cloud forest reserve. Brenesia 18:101-116.

Levey, D. J. 1986. Methods of seed processing by birds and seed deposition patterns. Pages 147-158 in A. Estrada and T. H. Fleming, editors. Frugivory and seed dispersal. W. Junk, Dordrecht, The Netherlands.

- 1987. Seed size and fruit-handling techniques of avian frugivores. American Naturalist 129:471-485.

Levey, D. J., and A. Grajal. 1991. Evolutionary implications of fruit processing limitations in Cedar Waxwings. American Naturalist 138:171-189.

Levey, D. J., T. C. Moermond, and J. S. Denslow. 1984. Fruit choice in neotropical birds: the effect of distance between fruits on preference patterns. Ecology 65:844-850.

Lieberman, D., J. B. Hall, M. D. Swaine, and M. Lieberman. 1979. Seed dispersal by baboons in the Shai Hills, Ghana. Ecology 60:65-75.

Lieberman, M., and D. Lieberman. 1986. An experimental study of seed ingestion and germination in a plant-animal assemblage in Ghana. Journal of Tropical Ecology 2:113126.

McKey, D. 1975. The ecology of coevolved seed dispersal systems. Pages 159-191 in L. E. Gilbert and P. H. Raven, editors. Coevolution of animals and plants. University of Texas Press, Austin, Texas, USA.

Murray, K. G. 1986. Consequences of seed dispersal for gap-dependent plants: relationships between seed shadows, germination requirements, and forest dynamic processes. Pages 187-198 in A. Estrada and T. H. Fleming, editors. Frugivores and seed dispersal. W. Junk, Dordrecht, The Netherlands.

- 1987. Selection for optimal fruit crop size in birddispersed plants. American Naturalist 129:18-31.

- 1988. Avian seed dispersal of three neotropical gapdependent plants. Ecological Monographs 58:271-298.
Murray, K. G, K. Winnett-Murray, E. A. Cromie, M. Minor, and $\mathrm{E}$. Meyers. In press. The influence of seed packaging and fruit color on feeding preferences of American Robins. Vegetatio.

Noble, J. C. 1975. The effects of emus (Dromaius novaehollandiae Latham) on the distribution of the nitre bush (Nitraria billardieri DC.). Journal of Ecology 63:979-984.

Noble, J. C., and R. D. B. Whalley. 1978. The biology and autecology of Nitraria L. in Australia. II. Seed germination, seedling establishment and response to salinity. Australian Journal of Ecology 3:165-177

Platt, W. J. 1976. The natural history of a fugitive prairie plant (Mirabilis hirsuta (Pursh) MacM.). Oecologia 22:399409.

Putz, F. E. 1993. On diarrhea. Bulletin of the Ecological Society of America 74:177.

Salmonson, M. G. 1978. Adaptations for animal dispersal of one-seeded juniper seeds. Oecologia 32:333-339.

Skeate, S. T. 1987. Interactions between birds and fruits in a northern Florida hammock community. Ecology 68:297309.

Sokal, R. R., and F. J. Rohlf. 1981. Biometry. Second edition. W. H. Freeman, New York, New York, USA.

Sorensen, A. E. 1981. Interactions between birds and fruit in a temperate woodland. Oecologia 50:242-249.

- 1983. Taste aversion and frugivore preference. Oecologia 56:117-120.

- 1984. Nutrition, energy and passage time: experiments with fruit preference in European blackbirds (Turdus merula). Journal of Animal Ecology 53:545-557.

Standley, P. C. 1937. Flora of Costa Rica. Publications of the Field Museum of Natural History, Botanical series 18.

Stiles, E. W. 1980. Patterns of fruit presentation and seed dispersal in bird-disseminated woody plants in the eastern deciduous forest. American Naturalist 116:670-688.

Temple, S. A. 1977. Plant-animal mutualism: coevolution with dodo leads to near extinction of plant. Science 197: 885-886.

Thompson, J. N., and M. F. Willson. 1979. Evolution of temperate fruit/bird interactions: phenological strategies. Evolution 33:973-982.

Utzurrum, R. C. B., and P. D. Heideman. 1991. Differential ingestion of viable vs. nonviable Ficus seeds by fruit bats. Biotropica 23:311-312.

Vazquez-Yanes, C. 1977. Germination of a pioneer tree (Trema guineensis Ficahlo), from equatorial Africa. Turrialba 23:301-302.

- 1980. Light quality and seed germination in Cecropia obtusifolia and Piper auritum from tropical rain forest in Mexico. Phyton 38:33-35.

Vazquez-Yanes, C., and A. Orozco-Segovia. 1984. Ecophysiology of seed germination in the tropical humid forests of the world: a review. Pages 37-50 in E. Medina, H. A. Mooney, and C. Vazquez-Yanes, editors. Physiological ecology of plants in the wet tropics. W. Junk, Dordrecht, The Netherlands.

Vazquez-Yanes, C., and H. Smith. 1982. Phytochrome control of seed germination in the tropical rain forest pioneer trees Cecropia obtusifolia and Piper auritum and its ecological significance. New Phytologist 92:477-485. 